UM VÍRUS ME DISSE

Creio que são

nada mais nada menos

que átomos pretensiosos

\title{
CONGELA DOR
}

descompassos internos

tempos diversos para o fim

sem tido a morte 
CRIAÇÃO

\section{SÃO VIVAS AS DANADAS}

Darwin, perfeito.

Mais lindo, porém,

é a DNA polimerase

trabalhando pela vida

Eduardo Triboni é estudante de Química da Universidade de São Paulo, USP, São Carlos

168 Interface_Comunic, Saúde, Educ 3 